\title{
Sporotrichosis: an Emergent Zoonosis in Rio de Janeiro
}

\author{
Mônica Bastos de Lima Barros, Tânia Maria Pacheco Schubach*/+, \\ Maria Clara Gutierrez Galhardo, Armando de Oliveira Schubach, Paulo Cezar \\ Fialho Monteiro**, Rosani Santos Reis**, Rosely Maria Zancopé-Oliveira**, \\ Márcia dos Santos Lazéra**, Tullia Cuzzi-Maya***, Tânia Cristina Moita

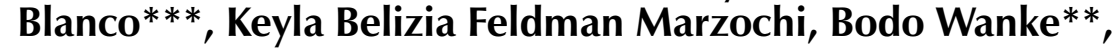 \\ Antonio Carlos Francesconi do Valle
}

\author{
Serviço de Dermatologia Infecciosa *Serviço de Zoonoses **Serviço de Micologia ***Serviço de Anatomia \\ Patológica, Centro de Pesquisa Hospital Evandro Chagas-Fiocruz, Av. Brasil 4365, 21045-900 \\ Rio de Janeiro, RJ, Brasil
}

During the period from 1987 to 1998, 13 cases of human sporotrichosis were recorded at the Research Center Evandro Chagas Hospital (CPqHEC) in Rio de Janeiro. Two of these patients related scratch by a sick cat. During the subsequent period from July 1998 to July 2000, 66 human, 117 cats and 7 dogs with sporotrichosis were diagnosed at the CPqHEC. Fifty-two humans (78.8\%) reported contact with cats with sporotrichosis, and 31 (47\%) of them reporting a history of a scratch or bite. This epidemic, unprecedented in the literature, involving cats, dogs and human beings may have started insidiously before 1998.

Key words: Sporothrix schenckii - sporotrichosis - emergent zoonosis - Rio de Janeiro - Brazil

Sporotrichosis is a mycosis caused by the dimorphic fungus Sporothrix schenckii, which can infect many different animal species, including man. The most frequent clinical presentation of the disease in humans and animals is the cutaneous form with or without regional lymphatic involvement. Following traumatic implantation in the skin this organism can cause cutaneous or subcutaneous infection which commonly shows lymphatic spread. Occasionally, however, the fungus may be inhaled causing infection in the lungs and, in predisposed individuals, may disseminate to other organs, mainly joints, bones and central nervous system (Kwon-Chung \& Bennet 1992).

S. schenckii occurs worldwide growing saprophytically as a mould in association with dead or decaying plant material. So far the fungus has been isolated as a saprobe from decomposing organic matter, decaying vegetation, such as thorns, straw, hay, wood and soil. For this reason, sporotrichosis is considered to be acquired during

${ }^{+}$Corresponding author. Fax: +55-21-2590.9988. E-mail: schubach@cpqhec.fiocruz.br

Received 18 January 2001

Accepted 16 May 2001 outdoor leisure activities or as an occupational hazard for many kind of workers such as: farmers, florists, gardeners, etc. whose occupation brings them into frequent and sometimes traumatic contact with plant material or soil (Kwon-Chung \& Bennet 1992). Occasionally, transmission of feline sporotrichosis to man has been reported and, veterinarians, technicians, and cat owners or caregivers are currently considered to be new categories at risk to acquire the mycosis (Kauffman 1999, Schubach et al. 2001).

Although sporotrichosis may be suggested by the presence of fungal structures in tissues or exudates by direct examination, the definitive diagnosis of Sporothrix infection requires isolation of the organism in culture at $25^{\circ} \mathrm{C}$ and its conversion to yeast-like form at $37^{\circ} \mathrm{C}$ (Kwon-Chung \& Bennet 1992).

Sporotrichosis is the most common subcutaneous mycosis in Latin America (Conti Diaz 1989). In Brazil, sporotrichosis has been reported since 1907 by Lutz and Splendore, especially in the states of São Paulo and Rio Grande do Sul (Freitas et al. 1965, Lopes et al. 1999).

EMERGENCE OF SPOROTRICHOSIS IN RIO DE JANEIRO

During the 12 year period from 1987 to 1998 , 13 cases of human sporotrichosis were recorded at 
the Infectious Dermatology Service of the Research Center Evandro Chagas Hospital (CPqHEC) in Rio de Janeiro: 8 (61.5\%) men and $5(38.5 \%)$ women aged on average 41 years, coming from the municipalities of Rio de Janeiro $(n=5 ; 38.4 \%)$, Duque de Caxias $(\mathrm{n}=2 ; 15.3 \%)$ and other municipalities $(\mathrm{n}=6 ; 46.3 \%)$. Five patients presented the localized cutaneous form, 6 presented the cutaneouslymphatic form and no information was obtained in 2 cases. Two of these patients, diagnosed in 1991 and 1997 respectively, related that their lesions had arisen at a site previously scratched by a sick cat.

During the subsequent two year period from July 1998 to July 2000, 66 human cases were recorded at CPqHEC. All of them had the diagnosis confirmed by the isolation of $S$. schenckii in culture. There was a predominance of women $(\mathrm{n}=$ $44 ; 66.7 \%)$ and the age ranged from 8 to 89 years (median: 41 years). The predominant clinical presentation was the cutaneous-lymphatic form ( $\mathrm{n}=$ $44 ; 66.7 \%)$ followed by the localized cutaneous form $(\mathrm{n}=16 ; 24.2 \%)$, disseminated cutaneous form $(n=4 ; 6.1 \%)$, mucosal form $(n=1 ; 1.5 \%)$ and the cutaneous-lymphatic form associated with mucosal form $(n=1 ; 1.5 \%)$. Most of the lesions were localized on the limbs as follows: upper limbs $(n=40$; $60.2 \%)$, lower limbs $(n=6 ; 9.2 \%)$ and both upper and lower limbs $(n=3 ; 4.5 \%)$. There were $6(9.2 \%)$ cases located on the face, $5(7.6 \%)$ cases had multiple site locations and $6(9.2 \%)$ cases had other site locations. Ten $(15.2 \%)$ patients presented a single lesion, $12(18.2 \%)$ presented 2 to 5 lesions and $44(66.6 \%)$ presented 6 or more lesions. Fiftytwo $(78.8 \%)$ reported home or professional contact with cats with a confirmed $(\mathrm{n}=31 ; 47 \%)$ or suspected $(\mathrm{n}=21 ; 31.8 \%)$ diagnosis of sporotrichosis, and $31(47 \%)$ of them reporting a history of a scratch or bite.
During this same 2-year period 117 cats and 7 dogs with sporotrichosis were diagnosed at the Zoonoses Service of CPqHEC. Among them, 72 $(61.5 \%)$ of cats were male with age between 3 month to 18 years (median: 2 years). Overall health was classified as good $(\mathrm{n}=63 ; 53.9 \%)$, regular $(\mathrm{n}$ $=29 ; 24.8 \%)$ and poor $(\mathrm{n}=25 ; 21.3 \%)$. The majority of the cutaneous lesions were located on head $(\mathrm{n}=57 ; 46.6 \%)$ and limbs $(\mathrm{n}=42 ; 35.9 \%)$. The lesions were solitary in 24 cats $(20.5 \%), 2$ to 9 in 50 animals $(42.8 \%)$, and 43 cats $(36.7 \%)$ showed 10 or more lesions. Ninety-three percent of cats (n $=109$ ) were treated with one or more of the following drugs: sodium iodide, itraconazole, fluconazole and terbinafine. Deaths occurred in 5 cats $(0.4 \%)$ before the initial treatment, and 3 animals $(0.2 \%)$ were lost at follow up.

The 124 animals came from a total of 62 residences. Of these, 84 animals belonged to 33 dwellings where one or more humans presented mycological proven sporotrichosis. Most of human and animal cases came from the municipality of Rio de Janeiro (Table and Figure).

Extensive epidemics involving wide geographic areas or a large number of cases are usually related to a common source of contamination in the environment (Dixon et al. 1991). Different animal species can be attacked by $S$. schenckii, but animal disease and transmission to man rarely occur. The zoonotic potential of feline sporotrichosis has been recognized since the 80's (Read \& Sperling 1982, Naqvi et al. 1993, Reed et al. 1993). Possibly due to the large number of organisms detected in feline tissues the transmission to man has been described even in the absence of a history of trauma (Rosser \& Dunstan 1990, Werner \& Werner 1994).

The cases reported here, most of them from underprivileged areas at the periphery of the city

TABLE

Distribution of human, feline and canine cases of sporotrichosis per municipality in the State of Rio de Janeiro, CPqHEC-Fiocruz (July 1998-July 2000)

\begin{tabular}{lccr}
\hline & & \multicolumn{2}{c}{ Cases of sporotrichosis } \\
\cline { 2 - 4 } Municipality & Human $(\%)$ & Feline/Canine (\%) & Total (\%) \\
\hline Rio de Janeiro & $22(33.4)$ & $51(41.1)$ & $73(38.5)$ \\
São João do Meriti & $14(21.2)$ & $32(25.9)$ & $46(24.3)$ \\
Duque de Caxias & $14(21.2)$ & $15(12.1)$ & $29(15.2)$ \\
Nilópolis & $2(3)$ & $20(16.1)$ & $22(11.6)$ \\
Belford Roxo & $5(7.6)$ & $4(3.2)$ & $9(4.7)$ \\
Others & $9(13.6)$ & $1(0.8)$ & $10(5.2)$ \\
Unknown & - & $1(0.8)$ & $1(0.5)$ \\
\hline Total & $66(100)$ & $124(100)$ & $190(100)$ \\
\hline
\end{tabular}




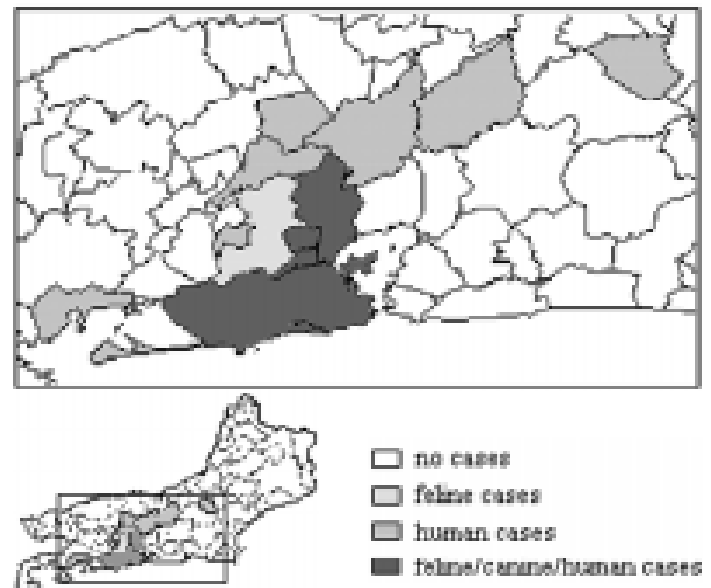

Map of the State of Rio de Janeiro. Municipalities where the human, feline and canine sporotrichosis cases came from, CPqHEC-Fiocruz (July 1998-July 2000).

of Rio de Janeiro, probably represent only a part of the problem and suggest that this outbreak in humans, mostly originated from feline sporotrichosis, may have started insidiously before 1998 .

Clinical, epidemiological, therapeutic schemes, mycological, pathological, immunological, molecular (Reis et al. 2000) and environmental studies are currently underway in an attempt to understand this epidemic, unprecedented in the literature, involving cats, dogs and human beings dispersed throughout extensive urban area.

\section{ACKNOWLEDGEMENTS}

To Marco Antonio Pereira de Melo and Rodrigo de Almeida Paes for technical support.

\section{REFERENCES}

Conti Diaz IA 1989. Epidemiology of sporotrichosis in Latin America. Mycopathologia 108: 113-116.
Dixon DM, Salkin IF, Duncan RA, Hurd NJ, Haines JH, Kemna ME, Coles FB 1991. Isolation and characterization of Sporothrix schenckii from clinical and environmental sources associated with the largest U.S. epidemic of sporotrichosis. J Clin Microbiol 29: 1106-1113.

Freitas D, Moreno G, Saliba A, Bottino J, Mós E 1965. Esporotricose em cães e gatos. Rev Fac Med Vet São Paulo 7: 381-387.

Kauffman CA 1999. Sporotrichosis. Clin Infect Dis 29: 231-236; quiz 237.

Kwon-Chung K, Bennet J 1992. Sporotrichosis. In K Kwon-Chung, J Bennet (eds), Medical Mycology The Pathogenic Fungi and the Pathogenic Actinomycetes, Lea \& Febiger, Philadelphia, p. 707-729.

Lopes J, Alves S, Mari C, Brum L, Westphalen J, Altermann M, Prates F 1999. Epidemilogy of sporotrichosis in the central region of Rio Grande do Sul. Rev Soc Bras Med Trop 32: 541-545.

Lutz A, Splendore A 1907. Sobre uma mycose observada em homens e ratos. Rev Med São Paulo 21: 433450.

Naqvi SH, Becherer P, Gudipati S 1993. Ketoconazole treatment of a family with zoonotic sporotrichosis. Scand J Infect Dis 25: 543-545.

Read SI, Sperling LC 1982. Feline sporotrichosis. Transmission to man. Arch Dermatol 118: 429-431.

Reed KD, Moore FM, Geiger GE, Stemper ME 1993. Zoonotic transmission of sporotrichosis: case report and review. Clin Infect Dis 16: 384-387.

Reis R, Schubach T, Guimarães A, Monteiro P, ZancopéOliveira R 2000. Molecular typing of Sporothrix schenckii strains isolated from clinical specimens in Rio de Janeiro, Brazil. In 14 th ISHAM, Buenos Aires, Argentina, May 8-12.

Rosser E, Dunstan R 1990. Sporotrichosis. In C Greene, Infectious Diseases of the Dog and Cat, WB Saunders Co., Philadelphia, p. 707-710.

Schubach T, Valle A, Gutierrez-Galhardo M, Monteiro $\mathrm{P}$, Reis R, Zancopé-Oliveira R, Marzochi K, Schubach A 2001. Isolation of Sporotrix schenckii from the nails of domestic cats (Felis catus). Med Mycol 39: 147-149.

Werner AH, Werner BE 1994. Sporotrichosis in man and animal. Int J Dermatol 33: 692-700. 
